\section{ADSORPTION OF WATER BY PROTEINS}

$I^{T}$

$T$ is recognized that proteins contain two types of hydrophilic groups capable of binding water by hydrogen-bond formation, namely, polar side-chains such as those from lysine, glutamic acid, tyrosine, etc., and the oxygen and nitrogen associated with peptide bonds in the peptide chains. Adsorption curves are of the typical $S$-shape separable into three segments, the first part, at low pressures, characteristic of Langmuir adsorption, a second part with a more or less linear relation between adsorbed amount and vapour pressure, and a third part corresponding with a large increase of amount adsorbed with increase of vapour pressure.

H. B. Bull (J. Amer. Chem. Soc., 66, 1499 ; 1944), who defines protein hydration as water released when moist protein in equilibrium with saturated water vapour at $25^{\circ}$ or $40^{\circ}$ is dried in vacuum for 24 hours at $105^{\circ}$, and calculates the free energy and heat changes in adsorption, concludes that the theory of multi-layer adsorption proposed by Brunauer, Emmett and Teller (J.Amer. Chem. Soc., 60, 309; 1938) explains the results in a very satisfactory manner. This extends the Langmuir theory of monolayer gaseous adsorption to the case where more than one layer of molecules are adsorbed, and the resulting curves were found to resemble those obtained in the experiments.

The results are believed to be consistent with the view that the protein molecules in the solid state are linked together to form coherent planes, the exposed surfaces of which are hydrophilic, and water is adsorbed between these planes. The final rise is thought to correspond with a saturation of exposed polar groups with water and the beginning of a process of solution of the protein. Heat coagulation of egg albumin seems to involve interaction between polar groups on neighbouring molecules, with a decrease in water-binding capacity.

It is thought that there is no direct relation between the amount of water held by a solid protein in a saturated atmosphere and the amount of water held by a protein when it is dissolved in water, the latter being mainly dependent on the total hydrophilic surface exposed to the water.

\section{EFFECT OF MULCHING ON THE SOIL}

$\mathrm{M}$ ULCHING is a recognized method of conserving soil moisture, but often several other effects of the treatment are noticeable. This is not, of course, unexpected when the mulch consists of organic material containing soluble plant nutrients in greater or less amount.

I. W. Wander and J. H. Gourley ${ }^{1}$ found that mulching with straw increased the contents of potassium, calcium, magnesium, phosphorus and boron in the soil, the effect being most marked for potassium, while H. Painter and G. F. Potter ${ }^{2}$ report that with young tung trees mulching reduced signs of potassium deficiency; and C. E. Baker ${ }^{3}$ found a mulch as effective as dressings of muriate of potash in increasing the potassium content of apple and peach leaves. These results may not be due entirely to potassium supplied by the mulch, as C. E. Baker* found that mulching with cinders or glass wool increased the potassium content of apple leaves, possibly because under the mulch a concentration of feeding roots near the soil surface, where potassium concentration is highest, occurred. Mulching with poor hay, also with apples, encouraged the production of surface feeding roots in addition to increasing soil moisture ${ }^{5}$.

The effects of mulching, however, are not always beneficial, and L. P. Latimer and A. P. Percival" found that although hay or seaweed mulches, as compared with grass covering, increased growth and fruit sizes in apples, sawdust used as a mulch did not have this effect, but did increase fruit and decrease leaf colour, suggesting that it had induced a slight nitrogen deficiency. W. A. Johnson ${ }^{7}$, using sawdust as a surface mulch for tomatoes, found that it decreased the soil nitrate content slightly and when incorporated in the soil, as mulch materials usually are eventually, depressed the soil nitrate appreciably so that heavier nitrate applications were required. The sawdust conserved soil moisture and caused the soil to be less compact, but repeated. sawdust mulches may have undesirable effects. L. M. Turk and N. L. Partridge ${ }^{8}$ found peat unsatisfactory as a mulch as it prevented light rain from reaching the soil, while loss by evaporation from the mulch continued. These ill-effects were not found when the mulch used allowed free percolation of water, and gravel, straw and sawdust were all effective in this respect.

1 Proc. Amer. Soc. Hort. Sci., 42, 1 (1943).

Proc. Amer. Soc. Hort. Sci., 42, 17 (1943).

- Proc. Amer. Soc. Hort. Sci., 39, 33 (1941).

"Proc. Amer. Soc. Hort. Sci., 48, 7 (1943).

${ }^{5}$ Proc. Amer. Soc. Hort. Sci., 42, 30 (1943).

- Proc. Amer. Soc. Hort. Sci., 44, 52 (1944).

"Proc. Amer. Soc. Hort. Sci., 44, 407 (1944).

${ }^{8}$ Proc. Amer. Soc. Hort. Sci., 38, 59 (1941).

\section{FORTHCOMING EVENTS}

\author{
Wednesday, April 4
}

Soctety of PUbuic ANalysts aNd Other analytical Chemists (at the Chemical Society, Burlington House, Piccadilly, London, W.1), at 5 p.m.-Mr. F. J. Macdonald : "The Freezing Point of Sour Milk"; Dr. H. Liebmann and Mr., A. D. Ayres: "The Electrometric Determination of Ascorbic Acid" 'Mr. H. W. Webb : "Magnetic Stirring
in the Electro-Deposition of Metals".

INSTITUTION OF ELEOTRICAL' ENGINEERS (RADIO SECTION) (joint meeting with the TELEVISION SocIETY) (at Savoy Place, Victoria Embankment, London, W.C.2), at 5.30 p.m.-Mr. D. C. Birkinshaw and Mr. D. R. Campbell: "Studio Technique in Television".

\section{Thursday, April 5}

INSTITUTION of EIECTRIOAL ENGINEERS (at Savoy Place, Victoria Embankment, London, W.C.2), at 5.30 p.m.-Mr. L. J. C. Connell, Mr. O. W. Humphreys and Mr. J. L. Bycroft: "The Place of Radiant, Dielectric and Eddy Current Heating in the Process Heating Field"' ROYAL AERONAUTIOAL SOCIETY (at the Institution of Mechanical
Engineers, Storey's Gate, St. James's Park, London, S.W.1), at 6.30 p.m.-Dr. A. G. Pugsley : "Modern Experimental Work on Aeroplane Structures".

\section{Friday, April 6}

INSTITUTION OF ELECTRICAY ENGINEERS (MEASUREMENTS SECTION) (at Savoy Place, Victoria Embankment, London, W.C.2), at 5.30 p.m. -Discussion on "Are Engineers Losing their Sense of Proportion on the Accuracy of Industrial Measurements?" (to be opened by Mr. H. D. Hawkes).

INSTITUTe of Physics (Scomtish BRANCH) (in the Natural Philosophy Department, The University, Glasgow), at 7.30 p.m.-Dr. W. Hume-Rothery, F.R.S. : "The Theoretical Interpretation of Alloy Structures". 